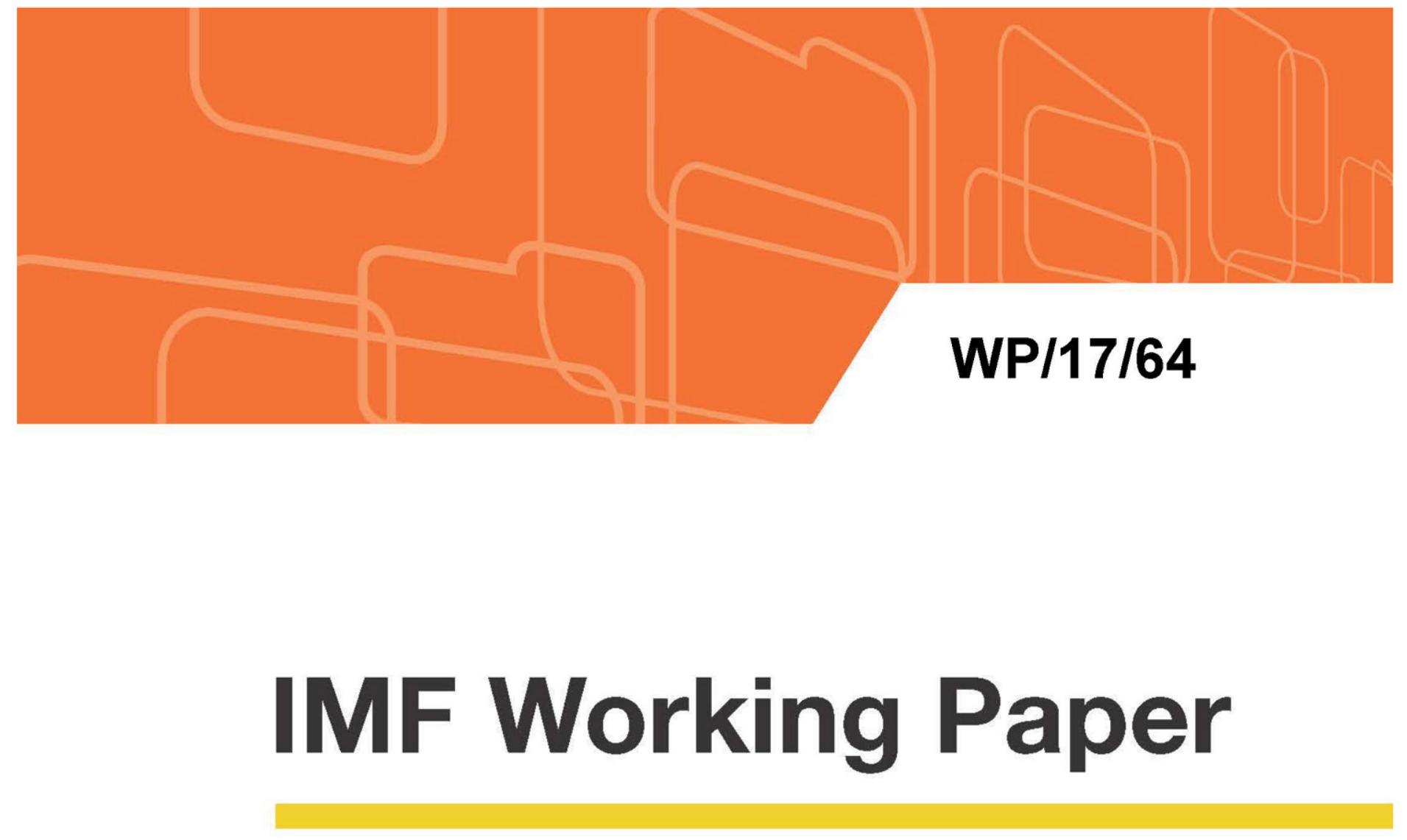

\title{
Fiscal Decentralization and Fiscal Policy Performance
}

By Moussé Sow and Ivohasina Razafimahefa

IMF Working Papers describe research in progress by the author(s) and are published to elicit comments and to encourage debate. The views expressed in IMF Working Papers are those of the author(s) and do not necessarily represent the views of the IMF, its Executive Board, or IMF management. 


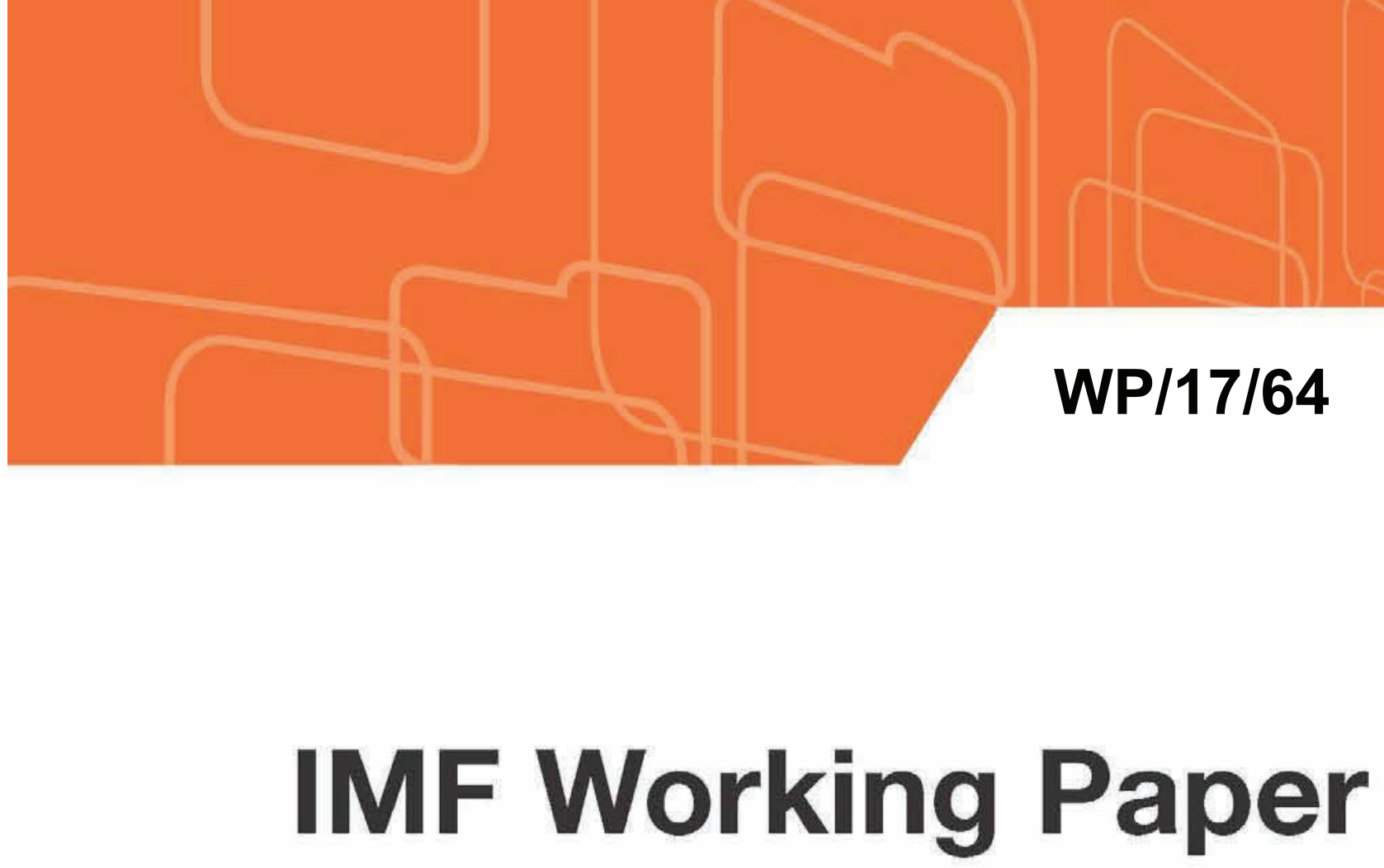

\section{Fiscal Decentralization and Fiscal Policy Performance}

By Moussé Sow and Ivohasina Razafimahefa

IMF Working Papers describe research in progress by the author(s) and are published to elicit comments and to encourage debate. The views expressed in IMF Working Papers are those of the author(s) and do not necessarily represent the views of the IMF, its Executive Board, or IMF management.

$$
\text { I N T ER N A T I O N A L MON E TAR Y F U N D }
$$




\title{
IMF Working Paper
}

Fiscal Affairs Department

\author{
Fiscal Decentralization and Fiscal Policy Performance \\ Prepared by Moussé Sow and Ivohasina F. Razafimahefa ${ }^{1}$ \\ Authorized for distribution by Era Dabla-Norris
}

March 2017

\begin{abstract}
IMF Working Papers describe research in progress by the author(s) and are published to elicit comments and to encourage debate. The views expressed in IMF Working Papers are those of the author(s) and do not necessarily represent the views of the IMF, its Executive Board, or IMF management.
\end{abstract}

\begin{abstract}
This paper explores the impact of fiscal decentralization on fiscal policy performance in a large sample of advanced and developing economies. The findings suggest that a larger share of decentralized expenditure is associated with a stronger fiscal balance; however, fiscal decentralization can lead to more pro-cyclical fiscal policy. Thus, the design and pace of fiscal decentralization need to be tailored to the specificities of the economy. Countries that have already established strong accountablity and budget management capacity at the local level can benefit from fiscal decentralization. In contrast, in economies prone to large volatility from internal and external shocks, the central government may need to retain a sufficient share of expenditure and revenue to conduct counter-cyclical policies. Finally, the pace of expenditure and revenue decentralization should be aligned.
\end{abstract}

JEL Classification Numbers: H77, E62, H62.

Keywords: Fiscal decentralization, fiscal balance, policy cyclicality.

Author's E-Mail Address: MSow@,imf.org; Irazafimahefa@imf.org

\footnotetext{
${ }^{1}$ The authors are grateful to E. Dabla-Norris, L. Jaramillo Mayor, C. Dieterich, P. Dohlman, R. A. Espinoza, N. Geng, M. Ghazanchyan, P. Lopes, A. Mourmouras and participants in the IMF Fiscal Affairs Department seminar for their useful comments.
} 
Table of Contents

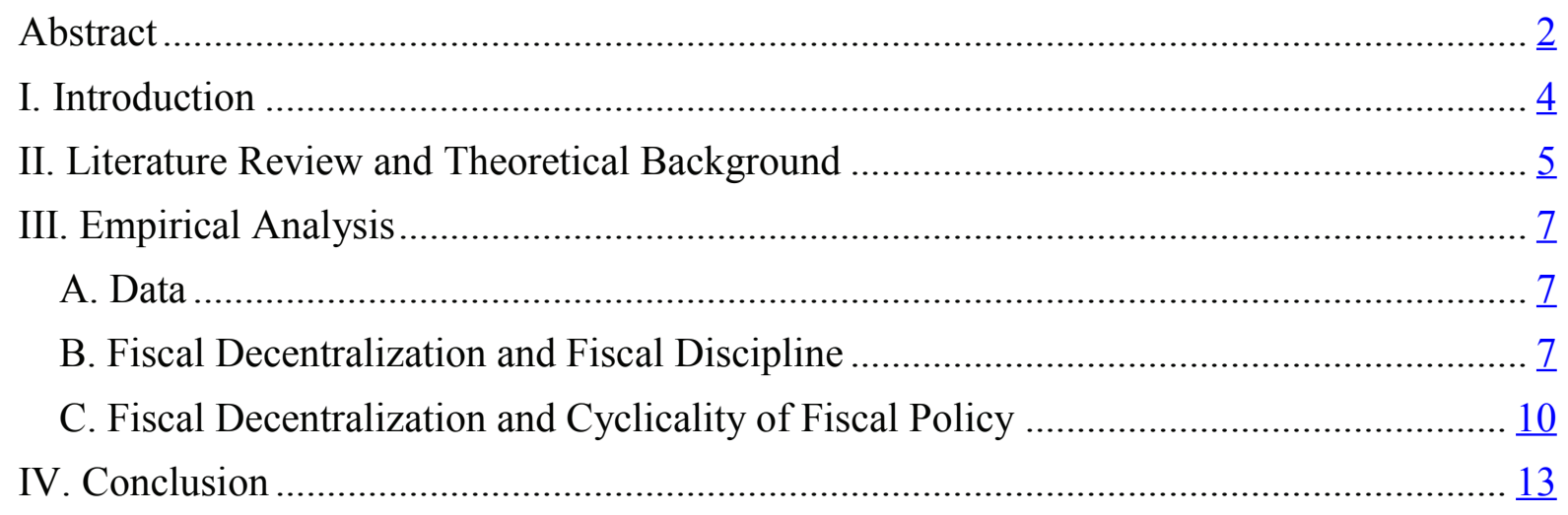




\section{INTRODUCTION}

Fiscal decentralization is the process of shifting the responsibilities of revenue collection and expenditure execution from the central to subnational authorities. As fiscal decentralization is generally lower in developing than in advanced economies, it becomes increasingly important to analyze whether fiscal decentralization should be expanded in the former group. The average share of expenditure managed at the subnational level is about 25 percent in developing economies, compared to about 40 percent in advanced economies. The average shares are respectively 23 percent and 37 percent on the revenue side.

This paper analyzes the impacts of fiscal decentralization on fiscal policy performance. These impacts are ambiguous and depend on the institutional context for decentralization (Dabla-Norris and Wade, 2002). Fiscal decentralization can help reduce expenditure as local authorities are under pressure to provide public goods at lower costs due to geographical closeness to the population and stronger accountability (Escolano et al., 2012; Governatori and Yim, 2012). Moreover, fiscal decentralization can allow for a better prioritization of public goods provisionthus, reduces wastes - as local authorities possess more information on the needs of the local population (Hayek, 1945; Tiebout, 1956; Musgrave, 1969). However, spending may increase if the decentralization of expenditure responsibilities is not matched with devolution of responsibilities on revenue collection. Furthermore, fiscal decentralization can lead to procyclical fiscal policy if the primary objective of local authorities is the provision of public goods and not macroeconomic stabilization. In particular, subnational balanced budget rules can improve fiscal discipline but lead to fiscal policy procyclicality.

This paper looks at the impacts of expenditure dencentralization and revenue devolution on the fiscal balance and on the reaction of fiscal policy to economic cycles. It aims to identify economic circumstances where fiscal decentralization can improve or worsen fiscal policy performance. This paper contributes to the existing literature in the following ways. First, it analyzes both expenditure and revenue decentralization. Second, it investigates both the fiscal balance and the cyclicality of fiscal policy. Most previous studies focused only partly on some of these issues. Third, this paper covers a large sample of countries, including developed and developing economies; most previous studies covered a specific country or a small set of countries. Fourth, this paper uses empirical techniques that allow for more refined analysis.

The findings suggest that fiscal decentralization is associated with stronger fiscal balance but also with a pro-cyclical fiscal policy. Thus, the degree and design of fiscal decentralization need to be tailored to the specific characteristics of the country and economy. Countries with strong accountability and budget management capacity at the local level can improve fiscal discipline (i.e. fiscal balance) through fiscal decentralization. However, economies that are prone to large volatility from internal of external shocks may need to retain a sufficient share of expenditure and revenue at the central level to allow conducting macroeconomic stabilization policies when needed. The paper is structured as follows. Section II reviews the existing literature and provides the theoretical background. Section III presents the empirical analysis, on both the fiscal discipline (i.e. fiscal balance) and the cyclicality of fiscal policy. Section IV summarizes the main findings. 


\section{Literature REVIEW AND ThEORETICAL BACKGROUND}

A large number of theoretical and empirical studies has examined the links between fiscal decentralization and fiscal policy performance.

\section{Merits}

Fiscal decentralization can improve the fiscal balance by allowing the provision of public goods and services at lower costs. The geographical closeness to final beneficiaries (i.e. voters) fosters accountability. It can put pressures on local governments to improve provision of public goods with minimum costs. It can also increase productive efficiency, reduce public expenditures, and improve the fiscal balance. Sow and Razafimahefa (2015) find that fiscal decentralization can improve the efficiency of public service delivery if some specific conditions are met. Escolano et al. (2012) and Governatori and Yim (2012) confirm the positive nexus between fiscal decentralization and fiscal balance for the European Union Member States. Neyapti (2010) supports this finding based on a panel of countries in Africa, Asia, North and South America, and Europe. In particular, the paper adds that the positive impact of fiscal decentralization on fiscal discipline - fiscal balance - increases with the population size. Baskaran (2010) shows that more devolution of spending authority to local governments tends to motivate sound fiscal policies and reduce public indebtedness in 17 OECD countries.

The ability of local governments to better match the preference of the local population can help contain expenditures. Local governments possess better access to local preferences and, consequently, have an informational advantage over the central government in deciding which provision of goods and services would best satisfy citizens (Hayek, 1945; Tiebout, 1956; Musgrave, 1969). In circumstances where expenditures need to be limited, local governments are in a better position to prioritize public goods and services to be provided. This informational advantage of local governments can help minimize the adverse impact of expenditure cuts on the population and alleviate social resistance to such a reduction.

Competition across local governments can also foster cost-effectiveness. Decentralization encourages competition among local governments to attract tax base, for instance by reducing local tax rates, and to search for innovative techniques to produce and provide public goods with limited resources. This competition enhances cost-effectiveness and reduces waste and corruption (Brennan and Buchanan, 1980). Consumers of public goods can move across jurisdictions where their needs are met, forcing local governments to improve efficiency of fiscal management (Tiebout, 1956). Such competition and the ensuing enhanced cost-effectiveness can also promote economic growth, and thereby, contribute to stronger fiscal performance (Oates, 1995).

\section{Risks}

The reliance on a "common pool" of resources may put pressures on the fiscal balance. Local policymakers may fail to fully internalize the cost of local spending when they can finance their marginal expenditure with central transfers or shared revenues that are funded by taxpayers in 
other jurisdictions. In such cases, the marginal benefits of additional spending would exceed the marginal costs. This behavior can lead to overspending, relaxation of tax collection, and deficit bias (Oates, 2006). The central government may not be able to enforce hard budget constraints on subnational governments that are consistent over time (Alfonso and Hauptmeier, 2009). Subnational governments may also expect their financing gap to be bailed-out by central governments, leading to a soft budget constraint and a deterioration of the fiscal balance (Rodden et. al, 2003).

Local governments' dependency on transfers can worsen the general government's fiscal balance. Higher reliance on transfers, particularly without debt limits, can worsen the overall balance (Rodden, 2002). Transfer-funded subnational expenditures can also become supplement (not substitute) to central government expenditures (Fornasari at al., 2000). Transfers may become a vicious cycle, with higher transfer-dependency leading to larger local governments' deficits and requiring larger transfers (De Mello, 2007). If subnational governments can finance a large part of their expenditures with their own revenue sources (taxes and fees), they have stronger incentives to behave in a fiscally responsible way (Governatori and Yim, 2012).

The production of public goods may require economies of scale. Expenditure containment expected from fiscal decentralization may be hypothetical if the economies of scale involved in the production and provision of public goods and services are large. Decentralization can also create unnecessary multiplication or overlapping of administrative procedures, due to shared competences across different territorial levels of administration over the same government function and unclear division of responsibilities among them.

Moreover, borrowing costs might be less favorable for local than central governments given that the former are perceived by markets as not holding a privileged policy role. Perceived difficulties in implementing consolidation plans under a decentralized economy-given the lower share of budget at the discretion of the central government - might lead markets to charge higher risk premia for the general government. Local governments may also lack the capacity to efficiently manage the budget and provide public services. The productivity of subnational administration could also be weaker due to the inability to attract skilled labor force (IMF, 2009). Fiscal decentralization can lead to misuse of public funds (Prud'homme, 1995); the greater proximity of subnational policy-makers to subnational interest groups can also make the former more sensitive than national policy-makers to lobbying for increased expenditures.

Fiscal decentralization may impede the conduct of macroeconomic stabilization policies, if a large share of taxes and spending is shifted to subnational governments. The central government would not have sufficient policy levers; policy priorities also often differ across government levels (Ter-Minassian, 1997; Tanzi, 1995). Even with similar amount of resources, fiscal decentralization can obstruct the ability of the central government to change the composition of revenues and expenditures to address shocks. Subnational governments' fiscal policies tend to be procyclical due to dissimilar incentive structure. Subnational governments are sometimes bound by balanced budget rules and borrowing rules that lead to pro-cyclical policies (Rodden and Wibbles, 2010). Competition among local governments constrains their ability to save during good times (Norregaard, 1997). Local governments have limited information about the general governments' economic cycle. Moreover, they may have very limited direct incentive to address 
economic cycle as their primary concerns are the delivery of local (instead of national) public services and short-term, instead of long-term, budget management.

\section{EMPIRICAL ANALYSIS}

\section{A. Data}

The sample consists of 64 countries from various geographical locations and stages of developments, spanning the period 1990 to 2012. Data were collected mostly from the IMF's Government Finance Statistics and World Economic Outlook, the World Bank's World Development Indicators, Eurostat, and OCED database. Full sample and variable definition are detailed in Appendix 1.

Fiscal decentralization is primarily measured as the share of expenditure executed by local authorities in general government expenditure. Local authorities include state, regional and municipal authorities. Fiscal performance is measured through both the fiscal balance and the cyclicality of fiscal policy. Due to difficulties in obtaining data from the various level of subnational governments, our fiscal decentralization index is obtained as the inverse of the ratio of central government share of expenditure over the general government expenditure-which measures fiscal centralization. ${ }^{2}$ The paper also uses revenue decentralization to investigate the impacts of the vertical fiscal imbalance, which is the ratio of local expenditures financed with local revenues. This paper analyzes fiscal policy performance from two angles, fiscal discipline (i.e. fiscal balance) and the cyclicality of fiscal policy. Most existing literature focuses solely on the fiscal discipline as the relevant measures of fiscal policy performance.

\section{B. Fiscal Decentralization and Fiscal Discipline}

This analysis starts by investigating the impact of fiscal decentralization on the structural fiscal balance. The model specification is based on an augmented fiscal reaction function. In addition to the reaction of the fiscal balance to the status of the economy and the level of public debt, a variable capturing the impact of fiscal decentralization is also introduced.

$$
S F B_{i t}=\alpha+\beta_{i}+\tau_{t}+\delta f d_{i t-1}+\varphi G D P g r_{i t-1}+v P D_{i t-1}+\sum_{k=1}^{K} \rho_{k} X_{k, i t-1}+\varepsilon_{i t}
$$

$S F B_{i t}$ is the structural fiscal balance, with $i$ and $t$ denoting respectively the panel and time dimensions. The structural fiscal balance is defined as the cyclically adjusted balance, corrected for one-off and other factors, such as asset and commodity prices and output composition effects. One merit of using the structural aspect of the fiscal balance, rather than the overall fiscal balance, is that the structural dimension measures discretionary actions of fiscal authorities,

\footnotetext{
${ }^{2}$ Although the inverse of fiscal centralization may not perfectly reflect fiscal decentralization, it offers the closest measurement (Dziobek et al., 2011).
} 
purging out any cyclical and temporary effects. The term $f d_{i t-1}$ is the fiscal decentralization index. This analysis focuses on the coefficient $\delta$. A positive $\delta$ indicates that a larger share of local expenditure in overall expenditure is associated with a stronger fiscal discipline. The terms $G D P g r_{i t-1}$ and $P D_{i t-1}$ correspond to GDP growth and public debt, respectively. While economic growth is expected to strengthen the government structural fiscal stance, the impact of the stock of debt depends on the size of the public debt (De Mello, 2000; Escolano et al., 2012).

Matrix $X_{k, i t-1}$ in equation (1) controls for additional macroeconomic and external characteristics that can affect the structural fiscal balance, such as the current account balance in percent of GDP, inflation and trade openness (Governatori and Yim, 2012). The set of control variables includes also corruption and political variables to capture the institutional and political features of each country. While political stability is expected to influence positively the structural fiscal balance, corruption is expected to have a negative effect, as corruption distorts public finance decisions and relates closely with public deficits (Adeb and Gupta, 2002; World Bank, 2012a; Oto-Peralías et al., 2013). $\beta_{i}$ and $\tau_{t}$ are country and time fixed effects, respectively. $\varepsilon_{i t}$ is a stochastic error term.

Various techniques are used to address the potential endogeneity of the fiscal decentralization variable. All right hand side variables are lagged by one period, including the fiscal decentralization. In addition, the two-stage least squares (2SLS) instrumental variable technique is used to better tackle the reverse causality concern, and mitigate the bias that could affect the estimates of the coefficient of interest $\delta$. The instrumental variables are population size and fractionalization. Decentralization incentives are stronger in countries with larger population size (Jiménez-Rubio, 2011; Escolano et al., 2012). Government fractionalization and ethnolinguistic fractionalization creates strong pressures for more fiscal decentralization (Neyapti, 2010).

Fiscal decentralization is found to be positively and robustly associated with stronger fiscal balance (Table 1). Shifting expenditure responsibilities to local authorities seems to help enhance fiscal surpluses or reduce fiscal deficits. This disciplinary effect is statistically significant and robust to the inclusion of control variables. Thus, it is not driven by omitted variable bias. This finding is in line with the existing literature, and seems to confirm that the stronger accountability generated by fiscal decentralization promotes fiscal discipline (Shah, 2005; Escolano et al., 2012, and Neyapti, 2013). GDP growth positively affects the structural balance, with a higher growth rate increasing (reducing) the surplus (deficit). This finding seems to indicate that fiscal policies are, in general, counter-cyclical in the sample of countries analyzed in this paper. Larger public debt seems to lead to lower fiscal deficits or higher fiscal surpluses as higher debt stock constrains the financing of a deficit.

The impact of fiscal decentralization on fiscal discipline is also analyzed by using the cyclically adjusted primary balance (CAPB). The CAPB has the merit of eliminating the legacy of previous governments and a budget item outside the control of the current government (i.e. interest payments), and is purged of cyclical factors. This analysis follows a two-step approach. First, the $\mathrm{CAPB}$ is derived from the following equation (2):

$$
\mathrm{PFB}_{i t}=\alpha+\beta_{i}+\tau_{t}+\delta P F B_{i t-1}+\gamma \text { OGap }_{i t}+\varphi \text { Inflation }_{i t}+\sigma \text { Trend }+v_{i t}
$$


Following Fatas and Mihov (2003), this fiscal reaction function allows for estimating the primary fiscal balance, cleaned of the inertia effect $\left(P F B_{i t-1}\right)$, cyclical effects (output gap) and other factors that could influence the fiscal balance such as the monetary policy actions (inflation). This model specification also controls for deviations that are purely driven by the trend evolution of the primary fiscal balance beyond the control of fiscal authorities. After excluding all these effects, the residual $\hat{v}_{i t}$ captures the primary balance purely driven by government's discretionary actions (Gali and Perotti, 2003), also known as the CAPB. In a second step, this estimated CAPB is used as the dependent variable in equation (3).

$\hat{v}_{i t}=\alpha+\beta_{i}+\tau_{t}+\delta f d_{i t-1}+\sum_{k=1}^{K} \rho_{k} X_{k, i t-1}+\xi_{i t}$

As in equation (1), $f d_{i t-1}$ is the fiscal decentralization variable and $X_{k, i t-1}$ is a set of control variables including macroeconomic, external, and political and institutional factors. $\xi_{i t}$ is the stochastic error term. $\beta_{i}$ and $\tau_{t}$ capture the country specific characteristics, and time dummies respectively. This equation is estimated via 2 SLS, with all right-hand-side variables introduced with a one period lag.

As shown in Table 2, fiscal decentralization is confirmed to be robustly associated with stronger fiscal discipline (Table 2). Devolution of expenditure responsibilities to the local authorities seem to improve overall fiscal management. This may be partly attributed to the impacts of subnational fiscal rules. The findings on public debt and GDP growth are also robust to the use of the CAPB as the dependent variable. As in the previous results, the lack of fiscal space imposes discipline on fiscal management and fiscal policy seems to be broadly countercyclical.

In addition to the expenditure decentralization, the role of revenue decentralization is also analyzed. The impact of revenue decentralization is investigated through the share of decentralized expenditure financed with decentralized revenue. This ratio is commonly referred to as the vertical fiscal imbalance It measures the degree of dependence of local authorities on own resources versus transfers from the central government (Bouton et al., 2008; Eyraud and Lusinyan, 2013). ${ }^{3}$ Two model specifications are estimated, based on the structural fiscal balance (equation 4) and the cyclically adjusted primary balance (equation 5) respectively, as follows:

$$
\begin{aligned}
& S F B_{i t}=\alpha+\beta_{i}+\tau_{t}+\delta v f i_{i t-1}+\varphi G D P g r_{i t-1}+v P D_{i t-1}+\sum_{k=1}^{K} \rho_{k} X_{i t-1}+\varepsilon_{i t} \\
& C A P B_{i t}=\alpha+\beta_{i}+\tau_{t}+\delta v f i_{i t-1}+\varphi G D P g r_{i t-1}+v P D_{i t-1}+\sum_{k=1}^{K} \rho_{k} X_{i t-1}+\varepsilon_{i t}
\end{aligned}
$$

\footnotetext{
${ }^{3}$ Eyraud and Lusinyan (2013) and Meloni, (2016) found that the general government fiscal balance improves by 1 percentage point of GDP for each 10 percentage point reduction in vertical fiscal imbalances.
} 
$v f i_{i t-1}$ is the vertical imbalance variable (i.e. the ratio of decentralized expenditure to decentralized revenue), and $C A P B_{i t}$ is derived from equation (2) estimated above.

Vertical fiscal imbalance seems to loosen fiscal discipline in some cases, although the findings are not statistically robust. ${ }^{4}$ Some results show that when local governments' own revenues are not sufficient to cover decentralized expenditure, the fiscal balance may deteriorate (Table 3). The over-reliance of local governments on transfers from the central government can loosen fiscal discipline. When local authorities can expect the central government to bail-out spending over-runs, they do not internalize the expenditure cost and tend to overspend. A recent study by Kotia and Lledo (2016) found that reducing excessive vertical fiscal imbalances complement a rules-based fiscal framework that is aimed at fostering fiscal discipline.

\section{Fiscal Decentralization and Cyclicality of Fiscal Policy}

The impact of decentralization on the cyclicality of fiscal policy is analyzed using a two-step approach. First, cyclicality coefficients are estimated for each country and each year. These cyclicality coefficients are then used as dependent variables to estimate the impact of fiscal decentralization.

In a first step, the cyclicality coefficients of fiscal policy are derived on a country-specific and yearly basis. The cyclicality of fiscal policy is estimated using the methodology in Aghion and Marinescu (2007) as follows:

$$
G_{i t}=\alpha_{i t}+\gamma_{i t} Y_{i \tau}^{*}+\varepsilon_{i \tau}
$$

where $G_{i t}$ is the general government final consumption expenditure and $\mathrm{Y}^{*}$ it is the output gap, or the business cycle, measured as the difference between the actual and potential GDP.

The choice of government expenditure as the dependent variable, instead of the overall/primary balance, is in line with Kaminsky et al. (2004) who argued that changes in expenditure reflect the policy orientation of the government. ${ }^{5}$ Potential GDP is obtained from the Hodrick-Prescott filter. The methodology in Aghion and Marinescu (2007) allows for generating country-specific and time-varying coefficients of the reaction of fiscal policy to the business cycle. The coefficient $\hat{\gamma}_{i t}$ indicates whether fiscal policy is pro-cyclical or counter-cyclical, on a countyspecific and yearly basis.

\footnotetext{
${ }^{4}$ It is to be noted that further analysis may be needed on the impact of the vertical fiscal imbalance, as the findings are not statistically robust (including when using alternative indicators of fiscal balance).

${ }^{5}$ Alternatively, changes in tax rates can also be used as an appropriate indicator of policy orientation. However, data on changes in tax rates are not readily available for the large sample of countries and period in this analysis.
} 
The second step analyzes the impact of fiscal decentralization on the estimated cyclicality coefficients. The equation is specified as follows:

$\hat{\gamma}_{i t}=\alpha+\beta_{i}+\tau_{t}+\gamma f d_{i t-1}+\sum_{k=1}^{K} \rho_{k} X_{k i t-1}+v_{i t}$

$\hat{\gamma}_{i t}$ are the estimates of the cyclicality of fiscal policy derived above, which vary across countries and over time; $f d_{i t-1}$ is the fiscal decentralization variable; $X_{k, t i}$ is a set of additional controls affecting the cyclicality of fiscal policy. To mitigate any potential bias and capture a causal relationship running from fiscal decentralization to the cyclicality of fiscal policy, the equation is estimated using the same 2SLS identification strategy as discussed earlier.

Fiscal policies seem to be broadly counter-cyclical, but vary across countries (Table 5). The mean estimates of the cyclicality coefficients indicate that governments tend to reduce expenditure when output is above potential (i.e. there is a positive output gap). In downturns (i.e. negative output gap), governments raise the public expenditure to boost domestic demand and support economic activity. Thus, fiscal policies seem to be broadly counter-cyclical. ${ }^{6}$

Fiscal decentralization is associated with pro-cyclical fiscal policies (Table 6). The positive coefficient of fiscal decentralization indicates that greater decentralization leads to a higher cyclicality coefficient. In other words, it increases fiscal policy pro-cyclicality or reduces counter-cyclicality, suggesting that fiscal decentralization has destabilizing effect on fiscal policy. This baseline result holds across various model specifications, controlling for macroeconomic and external variables, as well as political and institutional variables (columns 24). As a consequence of shifting large share of spending to the local governments, central governments have less room for maneuver to implement counter-cyclical fiscal measures. ${ }^{7}$ Moreover, local governments tend to conduct pro-cyclical fiscal policy, as their primary objective is the provision of public goods and not macroeconomic stabilization. As evidenced by Poghosyan et al. (2016), transferring to the center some cyclical spending and revenues can help if, for some reason, the local automatic stabilizers are not able to operate fully either because of local fiscal rules or because of financing constraints.

The policy pro-cyclicality generated by fiscal decentralization seems to occur mainly during periods of economic expansion (Table 7). Competition among local governments prevent them from reducing expenditures during periods of economic expansion. The geographical closeness to the voters, who are the final beneficiaries of the public goods and services, may limit the

\footnotetext{
${ }^{6}$ This finding is broadly in line with Talvi and Vegh (2005), Aghion and Marinescu (2007), Thornton (2009), and Kaminsky et al. (2004).

${ }^{7}$ Accordingly, the degree of fiscal decentralization may need to be taken into account when assessing the effective fiscal space.
} 
ability of local authorities to contain expenditures when the voters observe that the economythus revenue-is expanding.

The findings on the destabilizing effect of fiscal decentralization are robust to alternative model specifications (Table 8). While the magnitude of the coefficient changes somewhat, the inclusion of additional control variables still confirms that fiscal decentralization increases pro-cyclicality or reduces counter-cyclicality of fiscal policy. The destabilizing effect is also robust to the length of the smoothing window used to construct the cyclicality coefficients. These robustness tests suggest that the findings on the destabilizing effect of decentralization are neither driven by omitted variable bias or bias from the estimations of the cyclicality coefficients.

Also, there are some indications that vertical fiscal imbalances may lead to some pro-cyclical fiscal policy in some cases, although the results are not statistically robust (Tables 9 and 10). The following equation is estimated to analyze the impact of the vertical fiscal imbalance:

$\hat{\gamma}_{i t}=\alpha+\beta_{i}+\tau_{t}+\gamma v f_{i t-1}+\sum_{k=1}^{K} \rho_{k} X_{k i t-1}+v_{i t}$

where $\hat{\gamma}_{i t}$ are the estimates of the cyclicality of fiscal policy derived above, which vary across countries and over time, $v f_{i t-1}$ is the vertical fiscal imbalance measured as the ratio of decentralized expenditure to decentralized revenue, and the matrix $X_{k i t-1}$ is a set of control variables. The coefficients of the vertical fiscal imbalance variable are positive in most model specifications but are not statistically significant, except for one model (Tables 9 and 10). ${ }^{8}$ This may indicate some (weak) impact of vertical fiscal imbalance in creating fiscal policy proclycality.

\footnotetext{
${ }^{8}$ The robustness tests consist of adding more control variables and changing the smoothing parameters for the
} estimation of the cyclicality coefficients of fiscal policy. 


\section{Conclusion}

The findings of this paper suggest that fiscal decentralization can strengthen fiscal discipline. Fiscal decentralization can improve the fiscal balance as local authorities are under stronger pressures than the central government to provide more public goods with limited resources. This is due to their geographical closeness to the population, which fosters stronger accountability. Such pressures lead to the search for higher productive efficiency-in other words, production and provision of public goods at lower costs-, which reduces expenditures and improves the fiscal balance. Moreover, local authorities also possess better information about population's needs and preferences, limiting wastes of public goods, and reducing expenditures. However, expenditure decentralization can loosen fiscal discipline if it is not accompanied by commensurate decentralization of revenue collection responsibilities, as local governments may increase expenditure expecting that they will be financed by the central government.

Fiscal decentralization can lead to fiscal policy pro-cyclicality. Fiscal decentralization can constrain the ability of the central government to conduct macroeconomic stabilization policies as the policy levers - expenditure and revenue - are shifted to local governments. Local authorities tend to conduct pro-cyclical policies as their primary objective is the provision of public goods and not macroeconomic stabilization. Moreover, local governments have very limited information on national economic cycles.

Thus, the design and pace of fiscal decentralization need to be tailored to the specific characteristics of each country and economy. Countries that have established a strong system of accountability to the local population can benefit from fiscal decentralization. Strong budget management capacity at the local level is also required to ensure the ability to provide public goods at lower costs and reduce wastes and misuse of decentralized resources. Absent these prerequisites, fiscal decentralization has the potential to trigger major fiscal slippages; in particular, in countries with weak institutions, concentrating authority at the central level facilitates the establishment of processes and controls. Although not statistically robust, the analysis indicates that the paces of expenditure and revenue decentralization should be aligned. In cases where local authorities do not have sufficient revenue collection capacity, the pace of expenditure decentralization should be adjusted accordingly. Finally, the central government may need to retain sufficient share of expenditure and revenue to allow for conducting macroeconomic stabilization policies. This may be important for economies subject to frequent and large shocks. 
Table 1: Fiscal Decentralization and the Structural Fiscal Balance

\begin{tabular}{|c|c|c|c|c|}
\hline \multicolumn{5}{|c|}{ Dependent variable: Structural fiscal balance (\% of GDP) } \\
\hline & $(1)$ & $(2)$ & $(3)$ & (4) \\
\hline \multirow[t]{2}{*}{$\mathbf{F D}_{(\mathrm{t}-1)}$} & $15.83 * *$ & $12.62 *$ & $17.94 * * *$ & $13.37 * *$ \\
\hline & $(2.448)$ & $(1.958)$ & $(2.729)$ & $(2.024)$ \\
\hline \multirow[t]{2}{*}{ Public debt(t-1) } & $1.760 * * *$ & $0.912 * *$ & $1.928 * * *$ & 0.608 \\
\hline & $(4.395)$ & $(2.340)$ & $(4.191)$ & $(1.355)$ \\
\hline \multirow[t]{2}{*}{ GDP $\operatorname{gr}_{(t-1)}$} & $0.091 *$ & 0.045 & 0.091 & 0.037 \\
\hline & $(1.740)$ & $(0.805)$ & $(1.460)$ & $(0.571)$ \\
\hline \multirow[t]{2}{*}{$\mathrm{CAB}_{(\mathrm{t}-1)}$} & & $0.120 * * *$ & & $0.195^{* * *}$ \\
\hline & & $(4.074)$ & & $(5.386)$ \\
\hline \multirow[t]{2}{*}{ Inflation $_{(\mathrm{t}-1)}$} & & 0.131 & & 0.144 \\
\hline & & $(1.425)$ & & $(1.520)$ \\
\hline \multirow[t]{2}{*}{ Openness(t-1) } & & $4.461 * * *$ & & $6.224 * * *$ \\
\hline & & $(4.167)$ & & $(5.170)$ \\
\hline \multirow[t]{2}{*}{ Corruption $_{(\mathrm{t}-1)}$} & & & $-0.498^{*}$ & -0.348 \\
\hline & & & $(-1.779)$ & $(-1.410)$ \\
\hline \multirow[t]{2}{*}{ Polity2(t-1) } & & & -0.389 & $-0.758 * *$ \\
\hline & & & $(-1.179)$ & $(-2.440)$ \\
\hline Nb. of observations & 705 & 702 & 627 & 624 \\
\hline Countries & 46 & 46 & 40 & 40 \\
\hline Fisher ( $p$-value) & 0.000 & 0.000 & 0.000 & 0.000 \\
\hline Hansen OID ( $p$-value) & 0.488 & 0.66 & 0.128 & 0.222 \\
\hline KP underid. test & 0.000 & 0.000 & 0.000 & 0.000 \\
\hline \multicolumn{5}{|c|}{$\begin{array}{l}\text { Significance: } * 10 \% ; * * 5 \% \text { and } * * * 1 \% \text {. T-statistics based on robust standard } \\
\text { errors are reported in brackets. All specifications include country fixed effects } \\
\text { and time dummies. Fiscal decentralization (FD) is considered to be endogenous. } \\
\text { Instruments proposed are fractionalization of the government and legislating } \\
\text { system, and the population size. In addition, all right-hand-side variables are one } \\
\text { time lagged, including the FD variable. The Hansen's robust (to } \\
\text { heteroskedasticity and autocorrelation) p-values validate the over-identification } \\
\text { restrictions. Beside, with the Kleibergen-Paap's p values, we reject, at } 5 \% \text { level, } \\
\text { the null hypothesis that equations are under-identified. }\end{array}$} \\
\hline
\end{tabular}


Table 2: Fiscal Decentralization and the Cyclically Adjusted Primary Balance

\begin{tabular}{|c|c|c|c|c|}
\hline \multicolumn{5}{|c|}{ Dependent variable: $C A P B(\%$ of GDP) } \\
\hline & $(1)$ & $(2)$ & $(3)$ & $(4)$ \\
\hline \multirow[t]{2}{*}{$\mathbf{F D}_{(\mathrm{t}-1)}$} & $12.82 * *$ & $12.41 * *$ & $14.43 * * *$ & $14.68 * * *$ \\
\hline & $(2.215)$ & $(2.186)$ & $(2.631)$ & $(2.730)$ \\
\hline \multirow[t]{2}{*}{ Public debt $(\mathrm{t}-1)$} & $1.783 * * *$ & $1.755^{* * *}$ & $1.926^{* * *}$ & $1.901 * * *$ \\
\hline & $(5.771)$ & $(5.952)$ & $(5.881)$ & $(5.901)$ \\
\hline \multirow[t]{2}{*}{ GDP $\operatorname{gr}_{(\mathrm{t}-1)}$} & 0.047 & 0.043 & $0.064 *$ & $0.064 *$ \\
\hline & $(1.593)$ & $(1.384)$ & $(1.894)$ & $(1.754)$ \\
\hline \multirow[t]{2}{*}{$\mathrm{CAB}_{(\mathrm{t}-1)}$} & & 0.031 & & 0.047 \\
\hline & & $(1.454)$ & & $(1.576)$ \\
\hline \multirow[t]{2}{*}{ Inflation $_{(t-1)}$} & & $0.108^{*}$ & & $0.116^{*}$ \\
\hline & & $(1.715)$ & & $(1.808)$ \\
\hline \multirow[t]{2}{*}{ Openness (t-1) } & & 0.832 & & 0.726 \\
\hline & & $(1.135)$ & & $(0.920)$ \\
\hline \multirow[t]{2}{*}{ Corruption $(\mathrm{t}-1)$} & & & -0.196 & -0.186 \\
\hline & & & $(-1.222)$ & $(-1.186)$ \\
\hline \multirow[t]{2}{*}{ Polity $2(t-1)$} & & & -0.007 & -0.028 \\
\hline & & & $(-0.114)$ & $(-0.418)$ \\
\hline Nb. of observations & 870 & 863 & 792 & 788 \\
\hline Countries & 56 & 56 & 50 & 50 \\
\hline Fisher (p-value) & 0.000 & 0.000 & 0.000 & 0.000 \\
\hline Hansen OID ( $p$-value) & 0.144 & 0.108 & 0.019 & 0.02 \\
\hline KP underid. test & 0.000 & 0.000 & 0.000 & 0.000 \\
\hline
\end{tabular}

Significance: $* 10 \% ; * * 5 \%$ and $* * * 1 \%$. T-statistics based on robust standard errors are reported in brackets. All specifications include country fixed effects and time dummies. 
Table 3: Vertical Fiscal Imbalance and the Structural Fiscal Balance

Dependent variable: Structural fiscal balance (\% of GDP)

\begin{tabular}{|c|c|c|c|c|}
\hline & (1) & (2) & (3) & (4) \\
\hline \multirow[t]{2}{*}{$\mathrm{VFI}_{(\mathrm{t}-1)}$} & 0.44 & -1.387 & 1.207 & -0.49 \\
\hline & $(0.285)$ & $(-0.713)$ & $(1.360)$ & $(-0.426)$ \\
\hline \multirow[t]{2}{*}{ Public debt $(\mathrm{t}-1)$} & $1.278 * * *$ & -0.049 & $1.360 * * *$ & 0.100 \\
\hline & $(3.137)$ & $(-0.080)$ & $(3.635)$ & $(0.216)$ \\
\hline \multirow[t]{2}{*}{ GDP $\operatorname{gr}_{(t-1)}$} & $0.106^{*}$ & 0.027 & 0.073 & -0.016 \\
\hline & $(1.721)$ & $(0.385)$ & $(1.134)$ & $(-0.221)$ \\
\hline \multirow[t]{2}{*}{$\mathrm{CAB}_{(\mathrm{t}-1)}$} & & $0.173 * * *$ & & $0.184 * * *$ \\
\hline & & $(3.956)$ & & $(4.531)$ \\
\hline \multirow[t]{2}{*}{ Inflation $_{(\mathrm{t}-1)}$} & & 0.147 & & 0.145 \\
\hline & & $(1.465)$ & & $(1.498)$ \\
\hline \multirow[t]{2}{*}{ Openness(t-1) } & & $5.865 * * *$ & & $7.225 * * *$ \\
\hline & & $(3.710)$ & & $(4.812)$ \\
\hline \multirow[t]{2}{*}{ Corruption $_{(\mathrm{t}-1)}$} & & & -0.174 & -0.218 \\
\hline & & & $(-0.778)$ & $(-1.069)$ \\
\hline \multirow[t]{2}{*}{ Polity2(t-1) } & & & -0.368 & -0.383 \\
\hline & & & $(-0.964)$ & $(-1.067)$ \\
\hline $\mathrm{Nb}$. of observations & 659 & 656 & 598 & 595 \\
\hline Countries & 44 & 44 & 39 & 39 \\
\hline Fisher (p-value) & 0.000 & 0.000 & 0.000 & 0.000 \\
\hline Hansen OID (p-value) & 0.01 & 0.051 & 0.003 & 0.016 \\
\hline KP underid. test & 0.397 & 0.38 & 0.253 & 0.261 \\
\hline
\end{tabular}

Significance: * $10 \%$;* $5 \%$ and $* * * 1 \%$. T-statistics based on robust standard errors are reported in brackets. All specifications include country fixed effects and time dummies. Same as in table 1. 
Table 4: Vertical Fiscal Imbalance and the Cyclically Adjusted Primary Balance

\begin{tabular}{|c|c|c|c|c|}
\hline \multicolumn{5}{|c|}{ Dependent variable: $C A P B(\%$ of GDP) } \\
\hline & (1) & (2) & (3) & (4) \\
\hline \multirow[t]{2}{*}{$\operatorname{VFI}_{(t-1)}$} & 1.399 & 1.68 & 1.522 & 1.846 \\
\hline & $(1.288)$ & $(1.357)$ & $(1.481)$ & $(1.564)$ \\
\hline \multirow[t]{2}{*}{ Public debt $(t-1)$} & $2.105 * * *$ & $2.399 * * *$ & $2.073 * * *$ & $2.494 * * *$ \\
\hline & $(3.081)$ & $(2.887)$ & $(3.046)$ & $(2.978)$ \\
\hline \multirow[t]{2}{*}{ GDP $\operatorname{gr}(\mathrm{t}-1)$} & 0.044 & 0.04 & 0.045 & 0.049 \\
\hline & $(0.951)$ & $(0.668)$ & $(0.964)$ & $(0.774)$ \\
\hline \multirow[t]{2}{*}{$\mathrm{CAB}_{(\mathrm{t}-1)}$} & & -0.057 & & -0.059 \\
\hline & & $(-0.978)$ & & $(-0.907)$ \\
\hline \multirow[t]{2}{*}{ Inflation $_{(\mathrm{t}-1)}$} & & 0.012 & & 0.030 \\
\hline & & $(0.176)$ & & $(0.486)$ \\
\hline \multirow[t]{2}{*}{ Openness(t-1) } & & -0.292 & & -0.831 \\
\hline & & $(-0.218)$ & & $(-0.578)$ \\
\hline \multirow[t]{2}{*}{ Corruption $_{(\mathrm{t}-1)}$} & & & 0.426 & 0.488 \\
\hline & & & $(1.490)$ & (1.549) \\
\hline \multirow[t]{2}{*}{ Polity2(t-1) } & & & 0.103 & 0.05 \\
\hline & & & $(0.610)$ & $(0.253)$ \\
\hline $\mathrm{Nb}$. of observations & 796 & 789 & 744 & 740 \\
\hline Countries & 53 & 53 & 48 & 48 \\
\hline Fisher (p-value) & 0 & 0 & 0 & 0 \\
\hline \multirow{2}{*}{$\begin{array}{l}\text { Hansen OID (p-value) } \\
\text { KP underid. test }\end{array}$} & 0.88 & 0.887 & 0.823 & 0.924 \\
\hline & 0.412 & 0.447 & 0.383 & 0.421 \\
\hline
\end{tabular}


Table 5: Cyclicality of Fiscal Policy

(1) (2) (3)

\begin{tabular}{llll}
\hline Mean estimates (of cyclicality) & $\mathbf{- 0 . 1 0 2}$ & $\mathbf{- 0 . 2 0 2}$ & $\mathbf{- 0 . 1 5 3}$ \\
Standard deviations & 0.369 & 0.469 & 0.761 \\
Minimum & -3.692 & -4.622 & -10.858 \\
Maximum & 1.295 & 1.439 & 1.705 \\
\hline
\end{tabular}

Note: We use the Aghion and Marinescu (2007)'s Local Gaussian Weighted Ordinary Least Squares (LGWOLS) method to estimate the time-varying and country-specific standard errors. The year-to-year cyclicality coefficients are computed using all available observations for each country $i$, and performing a regression for each period $t$, with observations weighted by a Gaussian centered at the considered period t. Columns 2 and 3 show alternative estimates of the cyclicality coefficients, with the smoothing value initially set to $\sigma=5$ (benchmark, column 1) changed to $\sigma=3$ and $\sigma=7$ respectively.

Table 6: Fiscal Decentralization and the Cyclicality of Fiscal Policy

\begin{tabular}{|c|c|c|c|c|}
\hline \multicolumn{5}{|c|}{ Dependent variable: Cyclicality of fiscal policy } \\
\hline & (1) & $(2)$ & (3) & (4) \\
\hline \multirow[t]{2}{*}{$\mathbf{F D}_{(\mathrm{t}-1)}$} & $1.525 * *$ & $1.641 * *$ & $0.654 *$ & $0.816^{* *}$ \\
\hline & $(2.318)$ & $(2.491)$ & $(1.754)$ & $(2.214)$ \\
\hline \multirow[t]{2}{*}{ Public debt $(t-1)$} & $0.049 *$ & $0.089 * * *$ & 0.034 & $0.073 * * *$ \\
\hline & $(1.705)$ & $(2.801)$ & $(1.482)$ & $(2.935)$ \\
\hline \multirow[t]{2}{*}{$\mathrm{CAB}_{(\mathrm{t}-1)}$} & & $-0.005 * * *$ & & $-0.005 * *$ \\
\hline & & $(-2.822)$ & & $(-2.426)$ \\
\hline \multirow[t]{2}{*}{ Inflation $_{(\mathrm{t}-1)}$} & & -0.002 & & -0.001 \\
\hline & & $(-0.560)$ & & $(-0.327)$ \\
\hline \multirow[t]{2}{*}{ Openness (t-1) } & & $-0.302 * * *$ & & $-0.280 * * *$ \\
\hline & & $(-3.697)$ & & $(-4.025)$ \\
\hline \multirow[t]{2}{*}{ Corruption $_{(t-1)}$} & & & 0.018 & 0.016 \\
\hline & & & $(1.572)$ & $(1.359)$ \\
\hline \multirow[t]{2}{*}{ Polity2(t-1) } & & & -0.002 & 0.002 \\
\hline & & & $(-0.354)$ & $(0.396)$ \\
\hline $\mathrm{Nb}$. of observations & 902 & 892 & 801 & 794 \\
\hline Countries & 57 & 57 & 50 & 50 \\
\hline Fisher (p-value) & 0.349 & 0.018 & 0.002 & 0.000 \\
\hline Hansen OID ( $p$-value) & 0.016 & 0.104 & 0.054 & 0.157 \\
\hline KP underid. test & 0.000 & 0.000 & 0.000 & 0.000 \\
\hline
\end{tabular}


Table 7: The Destabilizing Effect of Fiscal Decentralization: expansion vs. recession

\begin{tabular}{|c|c|c|c|c|c|c|}
\hline & \multicolumn{3}{|c|}{ Fiscal decentralization } & \multicolumn{3}{|c|}{ Vertical Imbalances } \\
\hline & $\begin{array}{l}\text { Time dummies } \\
\text { (1) }\end{array}$ & $\begin{array}{l}\text { Expansion } \\
(2)\end{array}$ & $\begin{array}{l}\text { Recession } \\
(3)\end{array}$ & $\begin{array}{l}\text { Time dummies } \\
\text { (4) }\end{array}$ & $\begin{array}{l}\text { Expansion } \\
(5)\end{array}$ & $\begin{array}{l}\text { Recession } \\
(6)\end{array}$ \\
\hline $\mathbf{F D}_{(\mathrm{t}-1)}$ & $\begin{array}{l}\mathbf{0 . 8 1 6 * *} \\
(2.214)\end{array}$ & $\begin{array}{l}\mathbf{0 . 7 3 3 *} \\
(1.705)\end{array}$ & $\begin{array}{l}\mathbf{0 . 1 1 7} \\
(0.164)\end{array}$ & & & \\
\hline $\operatorname{VFI}_{(t-1)}$ & & & & $\begin{array}{l}\mathbf{0 . 0 7 1} \\
(1.167)\end{array}$ & $\begin{array}{l}\mathbf{- 0 . 0 2 9} \\
(-0.458)\end{array}$ & $\begin{array}{l}\mathbf{- 0 . 0 6 5} \\
(-0.547)\end{array}$ \\
\hline Public debt $(t-1)$ & $\begin{array}{l}0.073 * * * \\
(2.935)\end{array}$ & $\begin{array}{l}0.058 \\
(1.469)\end{array}$ & $\begin{array}{l}0.071 * \\
(1.752)\end{array}$ & $\begin{array}{l}0.106^{* *} \\
(2.492)\end{array}$ & $\begin{array}{l}0.155 \\
(1.325)\end{array}$ & $\begin{array}{l}0.040 \\
(0.642)\end{array}$ \\
\hline $\mathrm{CAB}_{(\mathrm{t}-1)}$ & $\begin{array}{l}-0.005 * * \\
(-2.426)\end{array}$ & $\begin{array}{l}-0.001 \\
(-0.316)\end{array}$ & $\begin{array}{l}-0.007 * * * \\
(-2.821)\end{array}$ & $\begin{array}{l}-0.008 * * \\
(-2.148)\end{array}$ & $\begin{array}{l}0.002 \\
(0.436)\end{array}$ & $\begin{array}{l}-0.005 \\
(-1.452)\end{array}$ \\
\hline Inflation $_{(\mathrm{t}-1)}$ & $\begin{array}{l}-0.001 \\
(-0.327)\end{array}$ & $\begin{array}{l}-0.000 \\
(-0.003)\end{array}$ & $\begin{array}{l}0.010 \\
(1.209)\end{array}$ & $\begin{array}{l}-0.002 \\
(-0.418)\end{array}$ & $\begin{array}{l}-0.002 \\
(-0.247)\end{array}$ & $\begin{array}{l}0.012 \\
(1.199)\end{array}$ \\
\hline Openness(t-1) & $\begin{array}{l}-0.280 * * * \\
(-4.025)\end{array}$ & $\begin{array}{l}-0.394 * * * \\
(-3.327)\end{array}$ & $\begin{array}{l}-0.253 * * * \\
(-3.291)\end{array}$ & $\begin{array}{l}-0.380 * * * \\
(-4.290)\end{array}$ & $\begin{array}{l}-0.403 * * \\
(-2.272)\end{array}$ & $\begin{array}{l}-0.364 * * * \\
(-3.253)\end{array}$ \\
\hline Corruption $_{(t-1)}$ & $\begin{array}{l}0.016 \\
(1.359)\end{array}$ & $\begin{array}{l}0.025 \\
(1.282)\end{array}$ & $\begin{array}{l}0.028 * * \\
(1.983)\end{array}$ & $\begin{array}{l}0.036 * * \\
(2.077)\end{array}$ & $\begin{array}{l}0.034 \\
(0.923)\end{array}$ & $\begin{array}{l}0.010 \\
(0.465)\end{array}$ \\
\hline Polity $2(\mathrm{t}-1)$ & $\begin{array}{l}0.002 \\
(0.396) \\
\end{array}$ & $\begin{array}{l}-0.001 \\
(-0.211) \\
\end{array}$ & $\begin{array}{l}-0.005 \\
(-0.589) \\
\end{array}$ & $\begin{array}{l}0.005 \\
(0.387) \\
\end{array}$ & $\begin{array}{l}0.035 \\
(0.823) \\
\end{array}$ & $\begin{array}{l}-0.010 \\
(-0.773) \\
\end{array}$ \\
\hline Nb. of observations & 794 & 368 & 426 & 746 & 345 & 401 \\
\hline Countries & 50 & 50 & 50 & 48 & 48 & 48 \\
\hline Fisher ( $p$-value) & 0.000 & 0.000 & 0.000 & 0.000 & 0.000 & 0.000 \\
\hline Hansen OID ( $p$-value) & 0.157 & 0.034 & 0.221 & 0.121 & 0.07 & 0.318 \\
\hline $\mathrm{KP}$ underid. test & 0.000 & 0.000 & 0.028 & 0.458 & 0.142 & 0.411 \\
\hline
\end{tabular}

Significance: $* 10 \%$;* 5\% and $* * * 1 \%$. T-statistics based on robust standard errors are reported in brackets. All specifications include country fixed effects and time dummies. 
Table 8: Fiscal Decentralization and the Cyclicality of Fiscal Policy (robustness tests)

\begin{tabular}{|c|c|c|c|c|c|}
\hline \multicolumn{6}{|c|}{ Dependent variable: Cyclicality of fiscal policy } \\
\hline & $\begin{array}{l}\text { Baseline } \\
(1)\end{array}$ & $\begin{array}{l}\text { Controls } \\
\text { (2) }\end{array}$ & $\begin{array}{l}\lambda=100 \\
(3)\end{array}$ & $\begin{array}{l}\sigma=3 \\
(4)\end{array}$ & $\begin{array}{l}\sigma=7 \\
(5)\end{array}$ \\
\hline $\mathbf{F D}_{(\mathrm{t}-1)}$ & $\begin{array}{l}\mathbf{0 . 8 1 6} * * \\
(2.214)\end{array}$ & $\begin{array}{l}\mathbf{0 . 8 2 1} * * \\
(2.059)\end{array}$ & $\begin{array}{l}\mathbf{0 . 7 2 5} * * * \\
(3.261)\end{array}$ & $\begin{array}{l}\mathbf{- 0 . 1 2 5} \\
(-0.209)\end{array}$ & $\begin{array}{l}\mathbf{0 . 8 7 3} * * * \\
(3.187)\end{array}$ \\
\hline Public debt $(\mathrm{t}-1)$ & $\begin{array}{l}0.072 * * * \\
(2.935)\end{array}$ & $\begin{array}{l}0.007 \\
(0.289)\end{array}$ & $\begin{array}{l}0.070 * * * \\
(4.345)\end{array}$ & $\begin{array}{l}0.150 * * * \\
(4.070)\end{array}$ & $\begin{array}{l}0.033^{*} \\
(1.760)\end{array}$ \\
\hline $\mathrm{CAB}_{(\mathrm{t}-1)}$ & $\begin{array}{l}-0.005 * * \\
(-2.426)\end{array}$ & $\begin{array}{l}-0.001 \\
(-0.478)\end{array}$ & $\begin{array}{l}0.000 \\
(0.008)\end{array}$ & $\begin{array}{l}-0.014 * * * \\
(-3.796)\end{array}$ & $\begin{array}{l}-0.002 \\
(-1.525)\end{array}$ \\
\hline Inflation $_{(\mathrm{t}-1)}$ & $\begin{array}{l}-0.001 \\
(-0.327)\end{array}$ & $\begin{array}{l}0.000 \\
(0.150)\end{array}$ & $\begin{array}{l}-0.003 \\
(-1.335)\end{array}$ & $\begin{array}{l}-0.001 \\
(-0.160)\end{array}$ & $\begin{array}{l}-0.001 \\
(-0.581)\end{array}$ \\
\hline Openness $(\mathrm{t}-1)$ & $\begin{array}{l}-0.280 * * * \\
(-4.025)\end{array}$ & $\begin{array}{l}0.216^{* * * *} \\
(3.237)\end{array}$ & $\begin{array}{l}-0.079 * \\
(-1.765)\end{array}$ & $\begin{array}{l}-0.358 * * * \\
(-3.217)\end{array}$ & $\begin{array}{l}-0.171 * * * \\
(-3.324)\end{array}$ \\
\hline Corruption $_{(\mathrm{t}-1)}$ & $\begin{array}{l}0.016 \\
(1.359)\end{array}$ & $\begin{array}{l}0.005 \\
(0.561)\end{array}$ & $\begin{array}{l}-0.003 \\
(-0.368)\end{array}$ & $\begin{array}{l}0.032 * \\
(1.705)\end{array}$ & $\begin{array}{l}0.014 \\
(1.558)\end{array}$ \\
\hline Polity2(t-1) & $\begin{array}{l}0.002 \\
(0.396)\end{array}$ & $\begin{array}{l}-0.010 \\
(-1.122)\end{array}$ & $\begin{array}{l}0.004 \\
(1.326)\end{array}$ & $\begin{array}{l}0.014 \\
(0.906)\end{array}$ & $\begin{array}{l}-0.000 \\
(-0.076)\end{array}$ \\
\hline Nb. of observations & 794 & 794 & 794 & 794 & 794 \\
\hline Countries & 50 & 50 & 50 & 50 & 50 \\
\hline Fisher (p-value) & 0.000 & 0.000 & 0.000 & 0.000 & 0.000 \\
\hline Hansen OID ( $p$-value) & 0.157 & 0.000 & 0.337 & 0.517 & 0.028 \\
\hline KP underid. test & 0.000 & 0.000 & 0.000 & 0.000 & 0.000 \\
\hline
\end{tabular}

Significance: $* 10 \% ; * * 5 \%$ and $* * * 1 \%$. T-statistics based on robust standard errors are reported in brackets. All specifications include time dummies. In column 2, the first step estimations of the cyclicality coefficients include additional control variables. In column 3 , the smoothing parameter of the HP filter is set to $\lambda=100$. Columns 4 and 5 show alternative estimates of the cyclicality coefficients, with the smoothing value initially set to $\sigma=5$ (benchmark, column 1 ) changed to $\sigma=3$ and $\sigma=7$ respectively. 
Table 9: Vertical Fiscal Imbalance and the Cyclicality of Fiscal Policy

\begin{tabular}{|c|c|c|c|c|}
\hline \multicolumn{5}{|c|}{ Dependent variable: Cyclicality of fiscal policy } \\
\hline & (1) & (2) & (3) & (4) \\
\hline \multirow[t]{2}{*}{$\operatorname{VFI}_{(t-1)}$} & 0.074 & 0.139 & 0.046 & 0.071 \\
\hline & $(0.528)$ & $(0.881)$ & $(0.878)$ & $(1.167)$ \\
\hline \multirow[t]{2}{*}{ Public debt(t-1) } & 0.080 & $0.190 * *$ & 0.047 & $0.106^{* *}$ \\
\hline & $(1.174)$ & $(2.180)$ & $(1.505)$ & $(2.492)$ \\
\hline \multirow[t]{2}{*}{$\mathrm{CAB}_{(\mathrm{t}-1)}$} & & $-0.014 * *$ & & $-0.008 * *$ \\
\hline & & $(-2.034)$ & & $(-2.148)$ \\
\hline \multirow[t]{2}{*}{ Inflation $_{(\mathrm{t}-1)}$} & & $-0.01 *$ & & -0.002 \\
\hline & & $(-1.820)$ & & $(-0.418)$ \\
\hline \multirow[t]{2}{*}{ Openness $(\mathrm{t}-1)$} & & $-0.530 * * *$ & & $-0.380 * * *$ \\
\hline & & $(-4.254)$ & & $(-4.290)$ \\
\hline \multirow[t]{2}{*}{ Corruption(t-1) } & & & $0.030^{*}$ & $0.036^{* *}$ \\
\hline & & & $(1.703)$ & $(2.077)$ \\
\hline \multirow[t]{2}{*}{ Polity2(t-1) } & & & -0.000 & 0.005 \\
\hline & & & $(-0.005)$ & $(0.387)$ \\
\hline \multirow{2}{*}{$\begin{array}{l}\mathrm{Nb} \text {. of observations } \\
\text { Countries }\end{array}$} & 832 & 822 & 753 & 746 \\
\hline & 54 & 54 & 48 & 48 \\
\hline Fisher (p-value) & 0.889 & 0.203 & 0.017 & 0.000 \\
\hline Hansen OID ( $p$-value) & 0.238 & 0.516 & 0.041 & 0.121 \\
\hline $\mathrm{KP}$ underid. test & 0.428 & 0.475 & 0.402 & 0.458 \\
\hline
\end{tabular}

Significance: $* 10 \% ; * * 5 \%$ and $* * * 1 \%$. T-statistics based on robust standard errors are reported in brackets. All specifications include time dummies. 
Table 10: Vertical Fiscal Imbalance and the Cyclicality of Fiscal Policy (robustness tests)

\begin{tabular}{|c|c|c|c|c|c|}
\hline \multicolumn{6}{|c|}{ Dependent variable: Cyclicality of fiscal policy } \\
\hline & $\begin{array}{l}\text { Baseline } \\
\text { (1) }\end{array}$ & $\begin{array}{l}\text { Controls } \\
\text { (2) }\end{array}$ & $\begin{array}{l}\lambda=100 \\
(3)\end{array}$ & $\begin{array}{l}\sigma=3 \\
(4)\end{array}$ & $\begin{array}{l}\sigma=7 \\
(5)\end{array}$ \\
\hline $\operatorname{VFI}_{(t-1)}$ & $\begin{array}{l}\mathbf{0 . 0 7 1} \\
(1.167)\end{array}$ & $\begin{array}{l}\mathbf{- 0 . 0 4 8} \\
(-0.568)\end{array}$ & $\begin{array}{l}\mathbf{0 . 0 6 9 *} \\
(1.728)\end{array}$ & $\begin{array}{l}-\mathbf{0 . 0 8 2} \\
(-0.756)\end{array}$ & $\begin{array}{l}\mathbf{0 . 0 4 6} \\
(0.738)\end{array}$ \\
\hline Public debt $(t-1)$ & $\begin{array}{l}0.106 * * \\
(2.492)\end{array}$ & $\begin{array}{l}0.012 \\
(0.236)\end{array}$ & $\begin{array}{l}0.098 * * * \\
(3.959)\end{array}$ & $\begin{array}{l}0.117 * \\
(1.713)\end{array}$ & $\begin{array}{l}0.080 * * \\
(2.024)\end{array}$ \\
\hline $\mathrm{CAB}_{(\mathrm{t}-1)}$ & $\begin{array}{l}-0.008^{* *} \\
(-2.148)\end{array}$ & $\begin{array}{l}0.001 \\
(0.415)\end{array}$ & $\begin{array}{l}-0.003 \\
(-1.438)\end{array}$ & $\begin{array}{l}-0.008 \\
(-1.310)\end{array}$ & $\begin{array}{l}-0.006 \\
(-1.604)\end{array}$ \\
\hline Inflation $_{(\mathrm{t}-1)}$ & $\begin{array}{l}-0.002 \\
(-0.418)\end{array}$ & $\begin{array}{l}0.002 \\
(0.471)\end{array}$ & $\begin{array}{l}-0.004 \\
(-1.398)\end{array}$ & $\begin{array}{l}0.001 \\
(0.144)\end{array}$ & $\begin{array}{l}-0.004 \\
(-1.243)\end{array}$ \\
\hline Openness(t-1) & $\begin{array}{l}-0.380 * * * \\
(-4.290)\end{array}$ & $\begin{array}{l}0.284 * * * \\
(3.326)\end{array}$ & $\begin{array}{l}-0.147 * * * \\
(-2.940)\end{array}$ & $\begin{array}{l}-0.365 * * \\
(-2.417)\end{array}$ & $\begin{array}{l}-0.303 * * * \\
(-4.324)\end{array}$ \\
\hline Corruption $_{(\mathrm{t}-1)}$ & $\begin{array}{l}0.036^{* *} \\
(2.077)\end{array}$ & $\begin{array}{l}0.010 \\
(0.407)\end{array}$ & $\begin{array}{l}0.022 * * \\
(2.121)\end{array}$ & $\begin{array}{l}0.001 \\
(0.041)\end{array}$ & $\begin{array}{l}0.043 * * * \\
(2.832)\end{array}$ \\
\hline Polity2(t-1) & $\begin{array}{l}0.005 \\
(0.387)\end{array}$ & $\begin{array}{l}0.003 \\
(0.139) \\
\end{array}$ & $\begin{array}{l}0.012 \\
(1.080)\end{array}$ & $\begin{array}{l}0.019 \\
(0.663)\end{array}$ & $\begin{array}{l}0.012 \\
(1.177) \\
\end{array}$ \\
\hline Nb. of observations & 746 & 746 & 746 & 746 & 746 \\
\hline Countries & 48 & 48 & 48 & 48 & 48 \\
\hline Fisher ( $p$-value) & 0.000 & 0.000 & 0.000 & 0.003 & 0.003 \\
\hline Hansen OID ( $p$-value) & 0.121 & 0.001 & 0.022 & 0.744 & 0.08 \\
\hline KP underid. test & 0.458 & 0.458 & 0.458 & 0.458 & 0.458 \\
\hline
\end{tabular}

Significance: $* 10 \% ; * * 5 \%$ and $* * * 1 \%$. T-statistics based on robust standard errors are reported in brackets. All specifications include country fixed effects and time dummies. 


\section{References}

Abed, G.T. and Gupta, S. (2002) “Governance, Corruption, and Economic Performance” International Monetary Fund, Washington DC.

Afonso, A. and Hauptmeier, S. (2009) "Fiscal Behavior in the European Union: Rules, Fiscal Decentralization and Government Indebtedness" ECB Working Paper, No. 1054.

Agénor, P. R., McDermott, C. J. and Prasad, E. S. (2000) "Macroeconomic Fluctuations in Developing Countries: Some Stylized Facts” World Bank Economic Review, Vol.14 (2), pp. 251-85.

Aghion P. and Marinescu I. (2007) "Cyclical Budgetary Policy and Economic Growth: What Do We Learn from OECD Panel Data?” NBER Macroeconomics annual, Vol. 22, pp. 251-78.

Ahmad, E., Brosio, G. and Tanzi, V. (2008) "Local Service Provision in Selected OECD Countries: Do Decentralized Operations Work Better?” IMF Working Paper WP/08/67.

Baskaran, T. (2010) "On the Link Between Fiscal Decentralization and Public Debt in OECD Countries," Public Choice, Vol. 145: 351-378.

Bouton, L., Gassner, M. and Verardi, V. (2008) "Redistributing income under fiscal vertical imbalance" European Journal of Political Economy, Vol. 24, pp. 317-28.

Brennan, D. and J. Buchanan, J. (1980) "The Power to Tax: Analytical Foundations of a Fiscal Constitution" Cambridge University Press, Cambridge.

Dabla-Norris, E. and Wade, P. (2002) “The Challenge of Fiscal Decentralization in Transition Countries” IMF Working Paper WP/02/103.

Davoodi, H., Xie, D. and Zou, H. (1999) "Fiscal Decentralization and Economic Growth in the United States" Journal of Urban Economics, Vol. 45, pp. 228-39.

Davoodi, H. and Zou, H. F. (1998) "Fiscal Decentralization and Economic Growth: A Cross-country Study" Journal of Urban Economics, Vol. 43(2), pp. 244-57.

De Mello, L. (2000) "Fiscal Decentralization and Intergovernmental Fiscal Relations: A Cross-Country Analysis" World Development Vol. 28(2), pp. 365-80.

(2007) “Does Fiscal Decentralization Strengthen Social Capital? Cross-Country Evidence and the Experiences of Brazil and Indonesia" OECD Economics Department Working Papers, No. 825.

Dziobek, C., Gutierrez-Mangas, C. and Kufa P. (2011) "Measuring Fiscal Decentralization - Exploring the IMF's Databases" IMF Working Paper WP/11/126.

Escolano, J., Eyraud, L., Moreno-Badia, M., Sarnes, J. and Tuladhar, A. (2012) "Fiscal Performance, Institutional Design and Decentralization in European Union Countries" IMF Working Paper WP/12/45. 
Eyraud, L. and Lusinyan, L. (2013) "Vertical fiscal imbalances and fiscal performance in advanced economies” Journal of Monetary Economics, Vol. 60, pp. 571-87.

Fatás, A. and Mihov, I. (2003) "The Case for Restricting Fiscal Policy Discretion" Quarterly Journal of Economics, Vol. 118(4), pp. 1419-47.

Frankel, J.A., Vegh, C.A. and Vuletin, G. (2013) "On Graduation from Fiscal Pro-cyclicality" Journal of Development Economics, Vol. 100(1), pp. 32-47.

(2009) “Macro Policy Lessons for a Sound Design of Fiscal Decentralization" IMF Board Paper $\mathrm{SM} / 09 / 208$.

Gali, J., and R. Perotti, (2003) "Fiscal Policy and Monetary Integration in Europe" Economic Policy, Vol. 18(37), pp. 533-72.

Governatori, M. and D. Yim (2012) "Fiscal Decentralization and Fiscal Outcome," Economic Papers 468, European Commission.

Hayek, V. F. (1945) “The Use of Knowledge in Society”, American Economic Review, 35(4), pp. 519-530.

Jiménez-Rubio, D. (2011) “The Impact of Fiscal Decentralization on Infant Mortality Rates: Evidence from OECD Countries" Social Science \& Medicine, Vol. 73(9), pp. 1401-07.

(2011) "The Impact of Decentralization of Health Services on Health Outcomes: Evidence from Canada" Applied Economics, Vol. 43, pp. 3907-17.

Kaminsky, G. L., Reinhart, C. M. and Vegh, C. A. (2004), “When It Rains, It Pours: Pro-cyclical Capital Flows and Macroeconomic Policies” NBER Macroeconomics Annual, Vol. 19, pp. 11-82.

Meloni, O. (2016) “Electoral opportunism and vertical fiscal Imbalance” Journal of Applied Economics, Vol 19 (1), pp. 145-68.

Musgrave, R. (1969) “Theories of Fiscal Federalism”, Public Finance, 24(4), 521-32.

Neyapti, B. (2010) "Fiscal Decentralization and Deficits: International Evidence" European Journal of Political Economy, Vol. 26, pp. 155-66. $528-32$.

(2013) "Fiscal decentralization, fiscal rules and fiscal discipline” Economics Letters Vol. 121, pp.

Norregaard, J. (1997) “Intergovernmental Fiscal Relations: The Chinese System in Perspective” in People's Republic of China - Selected Issues, International Monetary Fund. 
Oates, W. E. (2006) "On the Theory and Practice of Fiscal Decentralization" Institute for Federalism and Intergovernmental Relations Working Paper, No. 5.

Oto-Peralías, D., Romero-Ávila D. and Usabiaga C., (2013) "Does fiscal decentralization mitigate the adverse effects of corruption on public deficits" European Journal of Political Economy, Vol. 32, pp. 20531.

Prud'homme, R. (1995) "The Dangers of Decentralization" The World Bank Research Observer, Vol. 10(2), pp. 201-20.

Rodden, J. (2002) "The Dilemma of Fiscal Federalism: Grants and Fiscal Performance around the World" American Journal of Political Science, Vol. 46(3), pp. 670-87.

Rodden, J., Eskeland, G. S. and Litvack, J. (2003) "Fiscal Decentralization and the Challenges of Hard Budget Constraint" The MIT Press.

Rodden, J. and Wibbels, E. (2009) "Fiscal Decentralization and the Business Cycle: An Empirical Study of Seven Federations" Economics and Politics, Vol. 22(1), pp. 37-67.

Shah, A. (2005) "Fiscal Decentralization and Fiscal Performance” World Bank, Policy Research Working Papers.

Sharma, C.K. (2012) "Beyond gaps and imbalances: restructuring the debate on intergovernmental fiscal relations” Public Administration, Vol. 90 (1), pp. 99-128.

Sow, M. and Razafimahefa, I. (2015) "Fiscal Decentralization and the Efficiency of Public Service Delivery," IMF Working Paper 15/59.

Talvi, E. and Vegh, C. (2005) "Tax Base Variability and Pro-cyclical Fiscal Policy" Journal of Development Economics, Vol. 78(1), pp. 156-90.

Tanzi, V. (1995) "Fiscal Federalism and Decentralization: A Review of Some Efficiency and Macroeconomic Aspects” The World Bank Research Observer, pp. 295-316.

Ter-Minassian, T. (1997) "Decentralization and Macroeconomic Management" IMF Working Paper $97 / 155$.

Thornton, J. (2007) "Fiscal Decentralization and Economic Growth Reconsidered" Journal of Urban Economics, Elsevier, Vol. 61(1), pp. 64-70.

Tiebout, C.M. (1956) “A Pure Theory of Local Expenditures” Journal of Political Economy, Vol. 64, pp. 416-24.

World Bank, (2012a) “Anticorruption. Costs and consequences of corruption” World Bank, Washington DC. 


\section{Appendices}

Appendix 1: countries, data coverage and sources

\begin{tabular}{|c|c|c|c|c|c|}
\hline Countries & coverage & sources & Countries & coverage & Sources \\
\hline Argentina & 1993-2004 & GFS, WEO & Korea & $2000-2012$ & OECD database \\
\hline Australia ${ }^{\mathbf{R}, \mathbf{E}}$ & $1990-2011$ & OECD database & Latvia & $1995-2012$ & Eurostat \\
\hline Austria & $1990-2012$ & Eurostat & Lesotho & $1990-2008$ & GFS, WEO \\
\hline Bahrain $^{\mathbf{T}}$ & $1990-2004$ & GFS, WEO & Lithuania & $1995-2012$ & Eurostat \\
\hline Belarus & $2001-2010$ & GFS, WEO & Luxembourg & $1990-2012$ & Eurostat \\
\hline Belgium & $1990-2012$ & Eurostat & Maldives & $1990-2011$ & GFS, WEO \\
\hline Bhutan & 1990-2009 & GFS, WEO & Malta & $1995-2012$ & Eurostat \\
\hline Bolivia & $1990-2007$ & GFS, WEO & Mauritius & $2000-2011$ & GFS, WEO \\
\hline Brazil & $1997-2012$ & GFS, WEO & Mexico & $1990-2012$ & GFS, WEO \\
\hline Bulgaria & $1995-2012$ & Eurostat & Mongolia & $1992-2012$ & GFS, WEO \\
\hline Canada & $1990-2010$ & OECD database & Netherlands & $1990-2012$ & Eurostat \\
\hline Chile & $1990-2012$ & GFS, WEO & New Zealand ${ }^{\mathbf{R}, \mathbf{E}}$ & $1990-2012$ & OECD database \\
\hline Croatia & $2002-2012$ & Eurostat & Norway & $1990-2012$ & Eurostat \\
\hline Cyprus & $1995-2012$ & Eurostat & Pakistan & $1990-2007$ & GFS, WEO \\
\hline Czech Republic & $1995-2012$ & Eurostat & Peru & $1995-2012$ & GFS, WEO \\
\hline Denmark & $1990-2012$ & Eurostat & Poland & $1995-2012$ & Eurostat \\
\hline Egypt & $2002-2012$ & GFS, WEO & Portugal & $1990-2012$ & Eurostat \\
\hline Estonia & $1995-2012$ & Eurostat & Romania & $1995-2012$ & Eurostat \\
\hline Finland & $1990-2012$ & Eurostat & Seychelles & $1993-2012$ & GFS, WEO \\
\hline France & $1990-2012$ & Eurostat & Singapore & $1990-2012$ & GFS, WEO \\
\hline Georgia & $1997-2012$ & GFS, WEO & Slovak Republic & $1995-2012$ & Eurostat \\
\hline Germany & $1990-2012$ & Eurostat & Slovenia & $1995-2012$ & Eurostat \\
\hline Greece & $1995-2012$ & Eurostat & South Africa & $1990-2012$ & GFS, WEO \\
\hline Hungary & $1995-2012$ & Eurostat & Spain & $1995-2012$ & Eurostat \\
\hline Iceland & $1995-2012$ & Eurostat & Sweden & $1993-2012$ & Eurostat \\
\hline India & $1990-2012$ & GFS, WEO & Switzerland & $1990-2012$ & Eurostat \\
\hline Indonesia & $1990-2004$ & GFS, WEO & Tunisia & $1990-2012$ & GFS, WEO \\
\hline Iran & $1990-2009$ & GFS, WEO & Turkey $\mathbf{R , E}$ & $1990-2012$ & OECD database \\
\hline Ireland & $1990-2012$ & Eurostat & United Kingdom & $1990-2012$ & Eurostat \\
\hline Israel & $1995-2012$ & OECD database & United States & $1990-2012$ & OECD database \\
\hline Italy & $1990-2012$ & Eurostat & Uruguay & $1999-2012$ & GFS, WEO \\
\hline Japan $^{\mathbf{R}, \mathbf{E}}$ & 1990-2012 & OECD database & Venezuela & 1990-2005 & GFS, WEO \\
\hline
\end{tabular}




\section{Appendix 2: variables definition and data sources}

\begin{tabular}{|c|c|c|}
\hline Variables & Description & Sources \\
\hline Expenditure decentralization & Fiscal decentralization - Expenditure side & \multirow{2}{*}{$\begin{array}{l}\text { Eurostat, GFS, OECD } \\
\text { and WEO }\end{array}$} \\
\hline Revenue decentralization & Fiscal decentralization - Revenue side & \\
\hline Structural FB & $\begin{array}{l}\text { Cyclically adjusted balance, corrected for one-off and other } \\
\text { factors, such as asset and commodity prices and output } \\
\text { compositions effects. } \\
\text { Current account balance }\end{array}$ & $\begin{array}{l}\text { World Economic } \\
\text { Outlook, WEO } 2012\end{array}$ \\
\hline Inflation & Changes in consumer price index & \multirow{6}{*}{$\begin{array}{l}\text { World Bank, World } \\
\text { Development } \\
\text { Indicators } 2014\end{array}$} \\
\hline Openness & Sum of exports and imports in percent of GDP & \\
\hline GDP growth & Growth rate of the GDP & \\
\hline PFB & $\begin{array}{l}\text { Primary fiscal balance is the difference between total } \\
\text { revenues and total expenditures excluding interest payment }\end{array}$ & \\
\hline Total population & Measures the size of the population & \\
\hline Real GDP pc & GDP per capita, PPP (constant 2011 international) & \\
\hline Public debt & Public debt in percent of GDP & $\begin{array}{c}\text { WEO and Ali Abbas } \\
\text { database }\end{array}$ \\
\hline Government fractionalization & $\begin{array}{l}\text { Probability that two deputies randomly picked from the } \\
\text { government parties will be of different parties. }\end{array}$ & $\begin{array}{l}\text { DPI2012 Database of } \\
\text { Political Institutions }\end{array}$ \\
\hline Corruption & Assessment of corruption within the political system. & ICRG database \\
\hline
\end{tabular}




\section{Appendix 3: Detailed descriptive statistics}

\begin{tabular}{|c|c|c|c|c|c|c|c|}
\hline$\underline{\text { Variable }}$ & Obs. & Mean & Advanced & EME & Std. Dev. & Min & $\operatorname{Max}$ \\
\hline FD expenditure (\%) & 1086 & 29.55 & 38.97 & 25.42 & 21.31 & 0.00 & 98.44 \\
\hline FD revenue $(\%)$ & 1129 & 27.37 & 36.81 & 23.45 & 19.81 & 0.00 & 0.74 \\
\hline Population size (in millions) & 1472 & 48.64 & 43.31 & 50.89 & 138.70 & 0.07 & 1236.69 \\
\hline Government fractionalization & 1381 & 0.29 & 0.29 & 0.29 & 0.29 & 0.00 & 1.00 \\
\hline Inflation & 1430 & 0.75 & 0.60 & 0.82 & 1.11 & -16.86 & 16.38 \\
\hline Openness & 1454 & 88.54 & 81.58 & 91.52 & 58.49 & 13.75 & 439.66 \\
\hline Corruption & 1280 & -2.72 & -3.52 & -2.32 & 1.31 & -5.00 & 0.67 \\
\hline Polity 2 & 1341 & 7.08 & 9.05 & 6.28 & 5.24 & -10.00 & 10.00 \\
\hline Current account balance & 1432 & -1.63 & 0.97 & -2.74 & 7.47 & -42.09 & 26.33 \\
\hline GDP growth & 1461 & 3.10 & 2.50 & 3.36 & 4.55 & -44.90 & 19.59 \\
\hline Public debt (in $\%$ of GDP) & 1332 & 55.29 & 59.33 & 53.45 & 33.49 & 3.69 & 289.55 \\
\hline Primary fiscal balance & 1365 & 0.07 & 0.42 & -0.09 & 4.16 & -27.93 & 19.90 \\
\hline Structural fiscal balance & 907 & -0.19 & -0.18 & -0.19 & 3.70 & -17.70 & 30.41 \\
\hline Vertical Imbalance & 953 & 1.43 & 1.16 & 1.57 & 3.03 & 0.00 & 64.76 \\
\hline GDP & 1467 & 545 & 1420 & 174 & 1560 & 0.22 & 16200 \\
\hline Output gap & 1446 & -0.01 & 0.00 & -0.01 & 0.08 & -0.58 & 0.25 \\
\hline Output gap $(\lambda=100)$ & 1446 & -0.01 & -0.01 & -0.01 & 0.13 & -0.76 & 0.46 \\
\hline Cyclicality of FP & 1342 & 6.37 & 14.16 & 2.91 & 21.64 & -49.04 & 159.33 \\
\hline Cyclicality of FP $(\lambda=100)$ & 1342 & 0.34 & 1.51 & -0.18 & 13.11 & -50.35 & 119.09 \\
\hline Cyclicality of FP $(\sigma=3)$ & 1342 & 7.34 & 15.07 & 3.91 & 25.20 & -114.03 & 182.74 \\
\hline Cyclicality of FP $(\sigma=7)$ & 1342 & 5.97 & 13.85 & 2.47 & 20.91 & -46.21 & 150.84 \\
\hline
\end{tabular}

VFI is the ratio between expenditure decentralization and revenue decentralization. 


\section{Appendix 4: First-step regressions}

Dependent variable: fiscal decentralization

\begin{tabular}{|c|c|c|c|}
\hline & $\begin{array}{l}\text { All countries } \\
(1)\end{array}$ & $\begin{array}{l}\text { Advanced } \\
(2)\end{array}$ & $\begin{array}{l}\text { EME } \\
(3)\end{array}$ \\
\hline Real GDP pc $\mathrm{ct}_{\mathrm{t}-1)}$ & $\begin{array}{l}-0.001 \\
(-1.14)\end{array}$ & $\begin{array}{l}-0.001 \\
(-0.76)\end{array}$ & $\begin{array}{l}-0.000 \\
(-0.47)\end{array}$ \\
\hline Public debt $(\mathrm{t}-1)$ & $\begin{array}{l}-0.016^{*} \\
(-1.79)\end{array}$ & $\begin{array}{l}-0.063^{* * * *} \\
(-3.53)\end{array}$ & $\begin{array}{l}0.004 \\
(0.48)\end{array}$ \\
\hline $\mathrm{CAB}_{\mathrm{t}-1)}$ & $\begin{array}{l}-0.001 \\
(-1.17)\end{array}$ & $\begin{array}{l}0.001 \\
(0.48)\end{array}$ & $\begin{array}{l}-0.001 \\
(-1.45)\end{array}$ \\
\hline Inflation $_{(\mathrm{t}-1)}$ & $\begin{array}{l}0.000 \\
(0.55)\end{array}$ & $\begin{array}{l}0.005 \\
(0.49)\end{array}$ & $\begin{array}{l}0.000 \\
(0.04)\end{array}$ \\
\hline $\operatorname{Trade}_{(\mathrm{t}-1)}$ & $\begin{array}{l}0.052^{* *} \\
(2.91)\end{array}$ & $\begin{array}{l}-0.023 \\
(-0.62)\end{array}$ & $\begin{array}{l}0.047 * * \\
(2.48)\end{array}$ \\
\hline Corruption $_{(\mathrm{t}-1)}$ & $\begin{array}{l}0.015^{* * * *} \\
(3.71)\end{array}$ & $\begin{array}{l}0.050 * * * \\
(4.85)\end{array}$ & $\begin{array}{l}-0.000 \\
(-0.05)\end{array}$ \\
\hline Polity $2_{(\mathrm{t}-1)}$ & $\begin{array}{l}0.003 \\
(0.73)\end{array}$ & $\begin{array}{l}-0.028 * * \\
(-2.15)\end{array}$ & $\begin{array}{l}0.013 * * \\
(2.56)\end{array}$ \\
\hline Government fract.(t-1) & $\begin{array}{l}-0.088 * * * \\
(-4.87)\end{array}$ & $\begin{array}{l}-0.107 * * * \\
(-4.07)\end{array}$ & $\begin{array}{l}-0.067 \\
(-2.73)\end{array}$ \\
\hline Fractionalization $_{(\mathrm{t}-1)}$ & $\begin{array}{l}0.054 \\
(1.14)\end{array}$ & $\begin{array}{l}-0.053 \\
(-0.53)\end{array}$ & $\begin{array}{l}0.036 \\
(0.69)\end{array}$ \\
\hline Population size $(\mathrm{t}-1)$ & $\begin{array}{l}-0.394 * * * \\
(-3.74)\end{array}$ & $\begin{array}{l}-0.587 * * * \\
(-3.56)\end{array}$ & $\begin{array}{l}-0.116 \\
(-1.33)\end{array}$ \\
\hline Observ. & 624 & 251 & 373 \\
\hline Countries & 40 & 14 & 26 \\
\hline Join significance test & 6.56 & 6.42 & 2.59 \\
\hline $\mathrm{F}(p$-value $)$ & 0.00 & 0.00 & 0.00 \\
\hline R-squared & 0.14 & 0.28 & 0.13 \\
\hline F- test for excluded inst. (p-value) & 0.00 & 0.00 & 0.01 \\
\hline KP under-identification (p-value) & 0.00 & 0.00 & 0.00 \\
\hline \multicolumn{4}{|c|}{$\begin{array}{l}\text { Note. Significance: } * 10 \%, * * 5 \% \text { and } * * * 1 \% \text { with robust } T \text {-statistics in parentheses. NR stands for natural resources. Fixed } \\
\text { effects are taken into consideration to control for all time-invariant characteristics and exploit within country variations. The } \\
\text { endogenous variable is the fiscal decentralization ratio and the instrumental variables are: the population size, and two } \\
\text { measures of fractionalization. The instrumental variables are significantly correlated with the endogenous regressor in almost } \\
\text { all cases (the p-values associated with the F-test for excluded instruments are }<0.05 \text { ). Additionally, using the Kleibergen- } \\
\text { Paap's (KP) p values, we reject, at } 5 \% \text { level, the null hypothesis that equations are under-identified. The instrumental } \\
\text { variables used are relevant i.e. correlated with the endogenous regressor. }\end{array}$} \\
\hline
\end{tabular}

